\title{
Effect of particles size range on iron ore flotation
}

\section{Efeito da faixa de tamanho de partículas na flotação de minério de ferro}

Neymayer Pereira Lima

Mining Engineer, Dr.,

VALE Brasil.

neymayer.lima@vale.com

George Eduardo Sales Valadão

Mining Engineer, Dr.,

Associate Professor, UFMG.

gvaladao@demin.ufmg.br

Antônio Eduardo Clark Peres

Metallurgical Engineer, Ph.D.,

Associate Professor, UFMG.

aecperes@demet.ufmg.br

\section{Resumo}

A flotação é um dos principais processos de concentração, sendo empregada para diversas classes de minerais (sulfetos, óxidos, silicatos, fosfatos, etc.), em relativamente ampla faixa de tamanhos de partículas. Na indústria de minério de ferro, a flotação reversa de quartzo tem sido empregada com sucesso para partículas abaixo de $150 \mu \mathrm{m}$, após a etapa de deslamagem. A elevada demanda por produtos de minérios de ferro torna a flotação o principal processo de concentração dessa indústria, sendo assim necessária uma melhor compreensão dos mecanismos do processo, assim como do efeito do tamanho das partículas nesse processo.

Foram realizados ensaios de flotação com três diferentes frações granulométricas de um minério de ferro itabirítico, obtidas por classificação em ciclones, após a etapa de deslamagem. Os resultados obtidos mostraram diferenças de comportamentos entre as três frações, com maior dosagem de eteramina para as frações grossa e fina flotadas separadamente. A flotação em separado apresentou maior sensibilidade às variações de processo, principalmente no que diz respeito à dosagem de eteramina e ao $\mathrm{pH}$. As diferenças granulométricas e de área superficial específica podem justificar as diferenças de comportamento observadas nos ensaios de flotação.

A flotação em separado das frações grossa e fina indicou aumento de 3 pontos percentuais na recuperação metálica, com redução no teor de $\mathrm{SiO}_{2}$ no concentrado, aumento de $30 \%$ na dosagem de eteramina e redução de $20 \%$ no consumo de amido de milho em comparação com a flotação em conjunto destas frações. Análise de viabilidade econômica indicou VPL positivo de 50 milhões de dólares com a separação entre os circuitos de flotação de grossos e finos para o minério estudado, considerando a produção de 10 milhões de toneladas por ano de pellet feed.

Palavras-chave: Flotação de minério de ferro, faixas de tamanho de partícula, reagentes de flotação.

\begin{abstract}
Flotation is one of the main concentration processes being employed for many classes of minerals (sulfides, oxides, silicates, phosphates, for example) at different particle sizes. In the iron ore industry, reverse quartz flotation has been successfully employed for particle sizes below $150 \mu m$ after the desliming process. The high demand for iron ore products has made flotation the main process for concentration in this industry, thus a better understanding of its mechanisms and the effect of the particle sizes in the process has become imperative.
\end{abstract}

Flotation tests were carried out with three different size fractions of an itabirite 
iron ore, obtained using cyclone classification after desliming. The results showed distinct behaviors of the different size ranges. Higher etheramine dosages are required when coarse and fine fractions are floated separately and also this procedure is more sensitive to variations in etheramine dosages and $p H$ values. The differences in particle size distributions and the specific surface area may explain the different flotation behavior of the distinct size fractions.

The split flotation circuits for coarse and fine particles indicated an increase of $3 \%$ points in the metallurgical recovery with reduction of $\mathrm{SiO}_{2}$ content in final concentrate, increase of etheramine dosage and reduction of corn starch dosage. Economic feasibility analysis indicated a positive net present value of 50 million of dollars with split circuits for coarse and fine particles, considering a production of 10 million tons per year of pellet feed.

Keywords: Iron ore flotation, particle size ranges, flotation reagents.

\section{Introduction}

Flotation has been employed for over 100 years to a wide range of minerals: sulfides, oxides, phosphates, silicates, coal and soluble salts. The development of the mineral industry has been influenced substantially from the discovery and utilization of flotation. A large part of the world production of iron ore, necessary for the production of steel in the levels of

where:

$\mathrm{Pf}=$ probability of flotation.

$\mathrm{Pc}=$ probability of collision between the particles.

$\mathrm{Pa}=$ probability of adhesion (thinning and rupture of the liquid film during the collision).

Ps = probability of forming a stable aggre-

where:

$\mathrm{dp}=$ particle diameter

Figure 1 illustrates the collision efficiencies calculated and obtained experimentally for the different sizes of particles, according to the general model of collision proposed by Sutherland (1948).

The results from Figure 1 indicate a considerable increase in the collision efficiency with the increase in the particle size.

The adhesion efficiency for the different sizes of the particles was obtained experimentally by Dai (1999), presenting a good adherence to the calculated values.

According to Oliveira (2006), the concept that the quicker and disproportional consumption of the collector by current consumption, only became possible in the last decades with the utilization of the flotation process on a large scale (Oliveira, 2006).

The flotation processes for iron ore, either in mechanical cells or in columns, are fed with particles with sizes between 10 and $150 \mu \mathrm{m}$, being the slimes removed as overflow in classification cyclones. This

$$
P f=P c . P a . P s
$$

gate, capable of supporting the turbulences inside the flotation machines.

The probability of collision has deserved the attention of various researchers (Flint \& Howarth, 1971; Reay \& Ratcliff, 1975; Anfruns \& Kitchener, 1977; Collins \& Jameson, 1978), who showed that Pc is directly related to physical variables such

$$
\mathrm{Ec} \approx(\mathrm{dp} / \mathrm{db})^{2}
$$

$\mathrm{db}=$ bubble diameter

This expression is in agreement with

$$
\mathrm{Ec} \approx \mathrm{dp}{ }^{1,5}
$$

fine particles, due to their greater specific surface area, causes a lower hydrophobic coverage of the coarse particles, which therefore are less floatable, is quite well known throughout the technical literature. This concept was initially supported by the experimental work of Robinson (1975), referring to the quartz-dodecylamine system and by Glembotsky (1968) referring to the pyrite-xanthate system. These authors have observed that a greater dosage of reagents is necessary to float larger particles.

In the iron ore industry reverse quartz flotation is carried out with the ad- wide range of particle sizes can affect the selectivity of the process given the possible differences in hydrophobicity, specific surface area, weight, etc.).

Some authors (Tomlinson et al., 1963; Gonzales, 1978) described the flotation mechanism through probabilistic concepts using the expression:

as: density, pulp viscosity, relative speed of the bubble-particle and, more specifically, the diameter of the particle and of the bubble. An expression firstly deduced by Collins \& Jameson (1978) shows that, for a given gas flow, the efficiency of the collision (Ec) would be expressed by:

experimental results obtained by Ray and Ratcliff (1975), who found the correlation:

dition of etheramine as collector and corn starch as iron oxides depressant. According to the work carried out by Brandão (2005), the explanation for the selectivity observed in the industry and in the laboratory is not related to the qualitative aspects of the adsorption of the collectors (primary ammonium salts) and depressants (starch), but to the quantitative aspects. Thus the starch is adsorbed extensively onto hematite and with lesser intensity onto quartz; in the following stage the cationic alkyletheramine collector could only be adsorbed in small quantities on hematite, yet achieves a much greater 
Figure 1

Calculated and experimental collision efficiencies using the general model of collision. Adapted from Sutherland

adsorption on quartz. In this way, after sequential conditioning with two reagents, hematite remains clearly hydrophilic and quartz, on the other hand, changes its hydrophilic character to predominantly hydrophobic.

Work carried out by Lima (2001)

Figure 2

Effect of the presence of ultrafine particles in flotation for different samples of iron ore. Adapted from Lima (2001).

\section{Materials and methods}

The sample used in this work represents an itabirite iron ore from the Iron Quadrangle. The characterization was performed through chemical analyses (global and by size range) and size distribution. After desliming, the sample was classified in order to obtain two size distribution fractions $(-150+45 \mu \mathrm{m}$ and $-45 \mu \mathrm{m})$, to be used in laboratory scale flotation tests with different reagent dosages (corn starch and etheramine) and $\mathrm{pH}$ values. The flotation tests were carried out

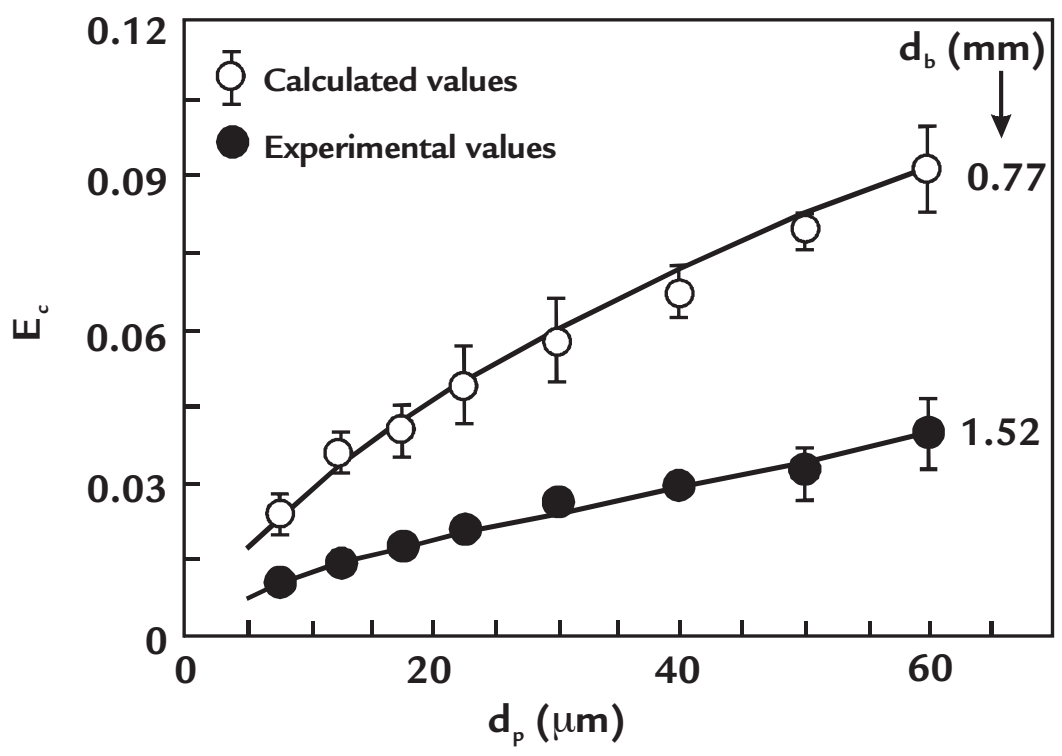

demonstrates the effect of the presence of ultrafine particles $(<10 \mu \mathrm{m})$ in the flotation of different iron ore samples. Figure 2 shows the $\mathrm{SiO}_{2}$ contents in the concentrate for the different ultrafine percentages.

The results in Figure 2 illustrate the effect of the presence of ultrafine particles

in iron ore flotation, therefore justifying the necessity for desliming. The high levels of $\mathrm{SiO}_{2}$ in concentrate in the case of the high ultrafine contents can be justified by the high consumption of collector by the ultrafine particles, caused by their high specific surface area.

\section{Effect of $-10 \mu \mathrm{m}$ particles in flotation response}

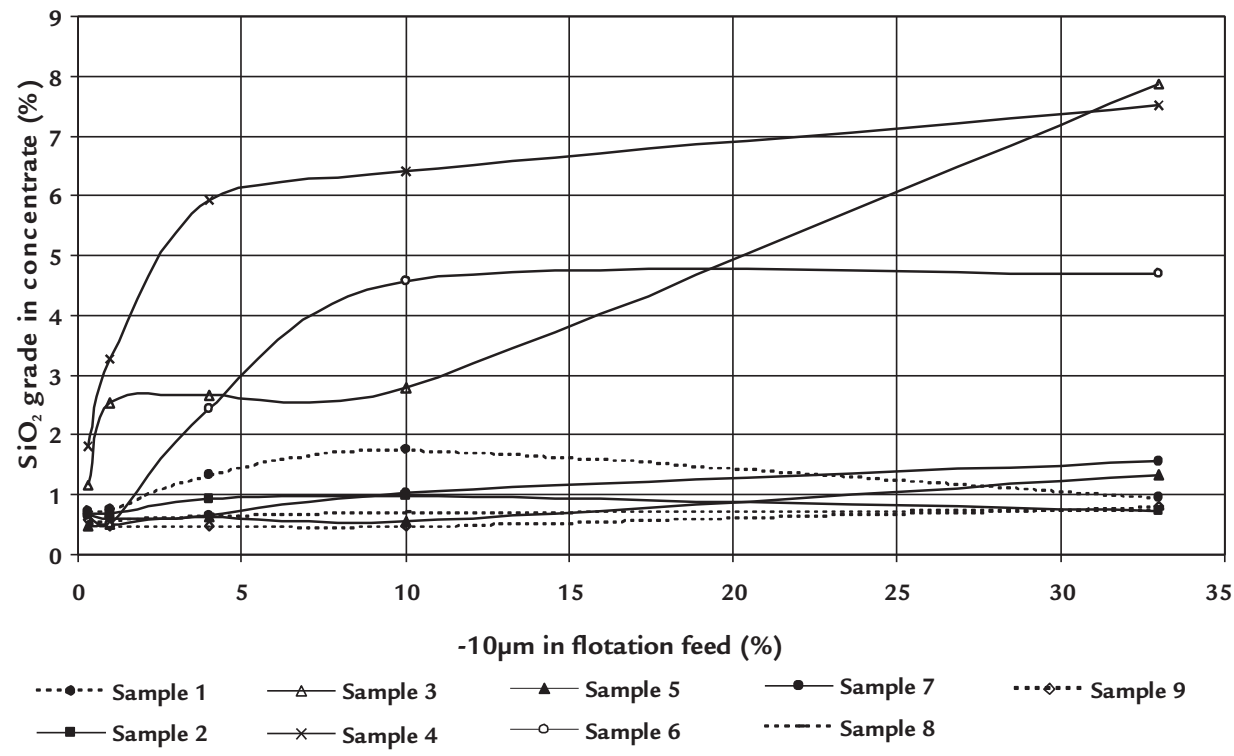

with coarse fraction $(-150+45 \mu \mathrm{m})$ and fine fraction $(-45 \mu \mathrm{m})$ and compared with the performance of the global fraction (-150 $\mu \mathrm{m}$, pellet feed product).

The tests aimed at evaluating the effect of different reagent dosages and $\mathrm{pH}$ values for the three size distribution fractions.

The flotation tests were carried out under the following conditions:

- Collector: etheramine with 30\% neutralization degree, prepared at $2 \%$ concentration by weight.

- Depressant: corn starch, prepared at $2 \%$ concentration by weight.

- Sodium hydroxide: utilized to adjust the flotation $\mathrm{pH}$, prepared at $5 \%$ concentration by weight.

- Percentage of solids in mass: $50 \%$.

Table 1 shows the levels of variables practiced during the flotation tests for each size fraction. 


\begin{tabular}{c|c|c|c}
\hline \multirow{2}{*}{ Conditions } & \multicolumn{3}{|c}{ Size fraction $(\mu \mathrm{m})$} \\
\cline { 2 - 4 } & $\mathbf{- 1 5 0}$ (global) & $\mathbf{- 1 5 0 + 4 5}$ (coarse) & $\mathbf{- 4 5}$ (fine) \\
\hline $\mathrm{pH}$ & 9.5 and 10.7 & 9.5 and 10.7 & 9.5 and 10.7 \\
\hline Etheramine $\left(\mathrm{g} / \mathrm{tSiO}_{2}\right)$ & 180 and 300 & 150 and 250 & 120 and 200 \\
\hline Corn starch $\left(\mathrm{g} / \mathbf{t}_{\text {feed }}\right)$ & 500 and 1000 & 500 and 1000 & 500 and 1000 \\
\hline
\end{tabular}

Table 1

Levels of variables practiced in the flotation tests.

\section{Results and discussion}

Table 2 shows the results of chemical analyses and the partition of the three size fractions obtained by laboratory screening scale after desliming.

\begin{tabular}{c|c|c|c}
\hline \multirow{2}{*}{ Size fraction $(\mu \mathrm{m})$} & \multirow{2}{*}{$\%$} & \multicolumn{2}{|c}{ Chemical assay (\%) } \\
\cline { 3 - 4 } & & $\mathbf{F e}$ & $\mathbf{S i O}_{\mathbf{2}}$ \\
\hline $\mathbf{- 1 5 0}$ (global) & 100.00 & 46.00 & 32.90 \\
\hline $\mathbf{- 1 5 0 + 4 5}$ (coarse) & 42.20 & 30.03 & 55.52 \\
\hline $\mathbf{- 4 5}$ (fine) & 57.80 & 57.67 & 16.38 \\
\hline
\end{tabular}

\section{Size distributions}

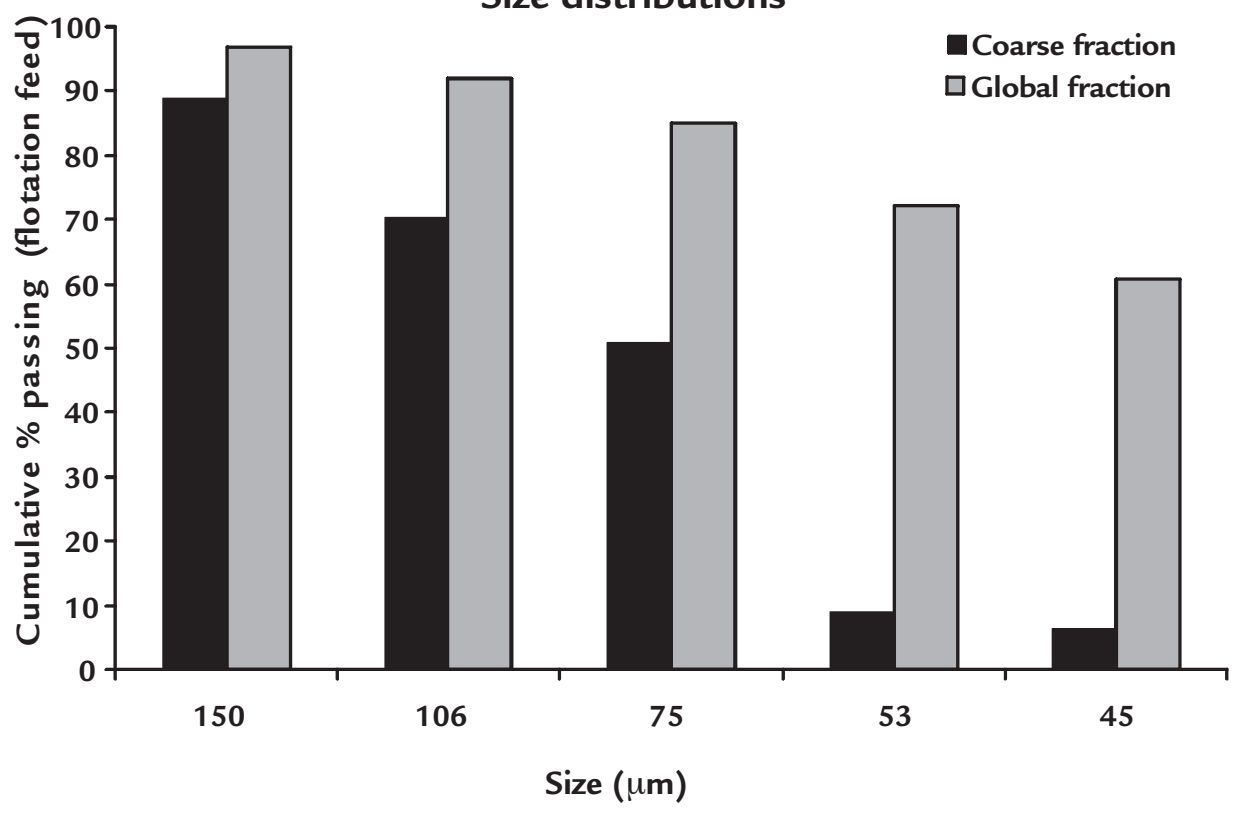

The global fraction presented high percentage of fine particles, approximately $60 \%$ passing $45 \mu \mathrm{m}$, whereas the coarse fraction presented only $6 \%$ of fine particles and $15 \%$ of particles retained in $150 \mu \mathrm{m}$.

Table 3 shows the specific surface area of the three size fractions.

Tables 4 and 5 show the results of iron recovery in concentrate, $\mathrm{SiO}_{2}$ content in concentrate and iron content in tailings for the three particle size fractions ob-
The mineralogical analysis indicated that the main mineral species present in all size fractions are hematite and quartz.

The particle size distribution of the coarse and global fractions is shown in Figure 3. The fine fraction presented $100 \%$ of particles passing $45 \mu \mathrm{m}$.

Table 2

Chemical analyses and partition of the global, coarse and fine fractions.
Figure 3

Size distributions in the flotation feed of the global and coarse fractions.

obtained with $500 \mathrm{~g} / \mathrm{t}$ of corn starch, $250 \mathrm{~g} / \mathrm{tSiO}_{2}$ of etheramine and $\mathrm{pH}$ equal to 9.5. The fine fraction presented the best results with $1000 \mathrm{~g} / \mathrm{t}$ of corn starch, $200 \mathrm{~g} / \mathrm{tSiO}_{2}$ of etheramine and $\mathrm{pH}$ equal to 10.7. The results on Tables 4 and 5 also show that the $\mathrm{SiO}_{2}$ content in concentrate presents a greater sensitivity to the variations in dosage of etheramine and $\mathrm{pH}$ for the coarse and fine fractions, lower sensitivity being observed for the global fraction $-150 \mu \mathrm{m}$. The differences

\begin{tabular}{c|c}
\hline Size fraction $(\mu \mathrm{m})$ & Specific surface area $\left(\mathrm{cm}^{2} / \mathrm{g}\right)$ \\
\hline$-150($ global $)$ & 550 \\
\hline$-150+45($ coarse $)$ & 450 \\
\hline$-45($ fine $)$ & 750 \\
\hline
\end{tabular}

Table 3

Specific surface area of three size fractions. 
in size, density and specific surface area can justify the differences in behavior observed in Tables 4 and 5.

The best results achieved for each particle size fraction are summarized on Table 6.

The results presented on Table 6 indicate that the best etheramine dosage is different for each size fraction. The coarse fraction requires higher etheramine dosage, lower corn starch dosage and yields

Table 4

Effect of etheramine dosage and $\mathrm{pH}$ (using $500 \mathrm{~g} / \mathrm{t}$ of corn starch).

Table 5

Effect of etheramine dosage and $\mathrm{pH}$ (using $1000 \mathrm{~g} / \mathrm{t}$ of corn starch).

Table 6 Summary of the best flotation tests results.

Table 7

Comparison between flotation of global and split particle size fractions. higher iron recovery in concentrate. The fine fraction yields a concentrate presenting the lowest silica content.

Table 7 shows a comparison between the results considering the flotation of split and global size fractions.

Splitting the flotation feed in coarse and fine fractions allowed 3\% gain in the metallurgical recovery, with reduction in the $\mathrm{SiO}_{2}$ content in final concentrate, with a greater consumption of ethera- mine and lower consumption of corn starch. These results indicate the possibility of increasing flotation efficiency when fed by narrow ranges of particle size distribution, due to the differences in behavior between them. Moreover, due to the greater specific surface area of the fine fraction particles, insufficient collector coverage on the coarse particles may occur when these fractions are floated together.

\begin{tabular}{|c|c|c|c|c|c|}
\hline $\begin{array}{l}\text { Size fraction } \\
(\mu \mathrm{m})\end{array}$ & $\begin{array}{c}\text { Etheramine } \\
\left(\mathrm{g} / \mathrm{tSiO}_{2}\right)\end{array}$ & $\mathrm{pH}$ & $\begin{array}{l}\text { Recovery of Fe in } \\
\text { concentrate (\%) }\end{array}$ & $\begin{array}{c}\mathrm{SiO}_{2} \text { in } \\
\text { concentrate (\%) }\end{array}$ & Fe in tailings $(\%)$ \\
\hline \multirow{4}{*}{-150 (global) } & 180 & \multirow{2}{*}{9.5} & 70.72 & 1.04 & 25.83 \\
\hline & 300 & & 60.99 & 0.70 & 30.55 \\
\hline & 180 & \multirow{2}{*}{10.7} & 75.79 & 1.62 & 23.07 \\
\hline & 300 & & 60.74 & 0.92 & 30.88 \\
\hline \multirow{4}{*}{$\begin{array}{l}-150+45 \\
\text { (coarse) }\end{array}$} & 150 & \multirow{2}{*}{9.5} & 78.65 & 1.18 & 9.89 \\
\hline & 250 & & 83.76 & 3.81 & 7.54 \\
\hline & 150 & \multirow{2}{*}{10.7} & 75.70 & 0.77 & 11.08 \\
\hline & 250 & & 84.70 & 1.16 & 7.33 \\
\hline \multirow{4}{*}{-45 (fine) } & 120 & \multirow{2}{*}{9.5} & 81.46 & 5.73 & 38.20 \\
\hline & 200 & & 63.06 & 1.33 & 45.72 \\
\hline & 120 & \multirow{2}{*}{10.7} & 82.69 & 2.30 & 32.28 \\
\hline & 200 & & 73.47 & 0.87 & 40.52 \\
\hline
\end{tabular}

\begin{tabular}{|c|c|c|c|c|c|}
\hline $\begin{array}{l}\text { Size fraction } \\
(\mu \mathrm{m})\end{array}$ & $\begin{array}{c}\text { Etheramine } \\
\left(\mathrm{g} / \mathrm{tSiO}_{2}\right)\end{array}$ & $\mathrm{pH}$ & $\begin{array}{l}\text { Recovery of Fe in } \\
\text { concentrate (\%) }\end{array}$ & $\begin{array}{c}\mathrm{SiO}_{2} \text { in } \\
\text { concentrate (\%) }\end{array}$ & Fe in tailings (\%) \\
\hline \multirow{4}{*}{-150 (global) } & 180 & \multirow{2}{*}{9.5} & 74.95 & 1.17 & 23.37 \\
\hline & 300 & & 65.77 & 0.67 & 28.77 \\
\hline & 180 & \multirow{2}{*}{10.7} & 76.76 & 1.35 & 22.50 \\
\hline & 300 & & 64.63 & 1.00 & 29.08 \\
\hline \multirow{4}{*}{$\begin{array}{l}-150+45 \\
\text { (coarse) }\end{array}$} & 150 & \multirow{2}{*}{9.5} & 79.06 & 1.17 & 9.68 \\
\hline & 250 & & 83.63 & 4.70 & 8.34 \\
\hline & 150 & \multirow{2}{*}{10.7} & 80.86 & 0.64 & 9.04 \\
\hline & 250 & & 82.73 & 1.90 & 8.10 \\
\hline \multirow{4}{*}{-45 (fine) } & 120 & \multirow{2}{*}{9.5} & 86.05 & 4.95 & 33.19 \\
\hline & 200 & & 75.01 & 0.86 & 39.19 \\
\hline & 120 & \multirow{2}{*}{10.7} & 89.25 & 2.39 & 26.25 \\
\hline & 200 & & 79.52 & 0.63 & 35.78 \\
\hline
\end{tabular}

\begin{tabular}{|c|c|c|c|c|c|c|}
\hline $\begin{array}{c}\text { Size } \\
\text { fraction } \\
(\mu \mathrm{m})\end{array}$ & $\begin{array}{c}\text { Etheramine } \\
\left(\mathrm{g} / \mathrm{tSiO}_{2}\right)\end{array}$ & $\begin{array}{c}\text { Corn starch } \\
\left(\mathrm{g} / \mathrm{t}_{\text {feed }}\right)\end{array}$ & $\mathrm{pH}$ & $\begin{array}{c}\text { Recovery of Fe in } \\
\text { concentrate (\%) }\end{array}$ & $\begin{array}{c}\mathrm{SiO}_{2} \text { in } \\
\text { concentrate (\%) }\end{array}$ & $\begin{array}{c}\text { Fe in } \\
\text { tailings (\%) }\end{array}$ \\
\hline $\begin{array}{c}-150 \\
\text { (global) }\end{array}$ & 180 & 1000 & 9.5 & 74.95 & 1.17 & 23.37 \\
\hline $\begin{array}{l}-150+45 \\
\text { (coarse) }\end{array}$ & 250 & 500 & 10.7 & 84.70 & 1.16 & 7.33 \\
\hline $\begin{array}{c}-45 \\
\text { (fine) }\end{array}$ & 200 & 1000 & 9.5 & 75.01 & 0.86 & 39.19 \\
\hline
\end{tabular}

\begin{tabular}{c|c|c|c|c|c|c}
\hline $\begin{array}{c}\text { Conditions of } \\
\text { flotation }\end{array}$ & $\begin{array}{c}\text { Etheramine } \\
\left(\mathrm{g} / \mathrm{tSiO}_{2}\right)\end{array}$ & $\begin{array}{c}\text { Corn starch } \\
\left(\mathrm{g} / \mathbf{t}_{\text {feed }}\right)\end{array}$ & $\mathrm{pH}$ & $\begin{array}{c}\text { Recovery of Fe in } \\
\text { concentrate (\%) }\end{array}$ & $\begin{array}{c}\mathrm{SiO}_{2} \text { in } \\
\text { concentrate (\%) }\end{array}$ & $\begin{array}{c}\text { Fe in } \\
\text { tailings (\%) }\end{array}$ \\
\hline $\begin{array}{c}\text { Coarse and } \\
\text { fine together }\end{array}$ & 180 & 1000 & 9.5 & 74.95 & 1.17 & 23.37 \\
\hline $\begin{array}{c}\text { Coarse and } \\
\text { fine separated }\end{array}$ & 236 & 789 & 10.0 & 77.67 & 0.95 & 21.53 \\
\hline
\end{tabular}




\section{Conclusions}

Flotation tests carried out in bench scale with three different particle size fractions of itabirite iron ore indicated distinct behaviors, as well as differences in the required dosages of etheramine and corn starch and in the $\mathrm{pH}$ values. Flotation in separate circuits for the coarse and fine fractions yielded an increase of $3 \%$ points in the metallurgical recovery with a reduction in the $\mathrm{SiO}_{2}$ content in the final concentrate, an increase of $30 \%$ in the consumption of etheramine, a reduction of $20 \%$ in the consumption of corn starch and a slightly higher $\mathrm{pH}$ level. In addition the results indicated that the separate flotation circuit presents a greater sensitivity to $\mathrm{SiO}_{2}$ content in concentrate with respect to variations in the etheramine dosage and $\mathrm{pH}$ value.

Economic feasibility analyses carried out on splitting the flotation circuits indicated a positive NPV (net present value) of 50 million of dollars, taking into consideration an increase of $3 \%$ in the metallurgical recovery, the increase in the cost of etheramine and the cost of acquiring the equipments (tanks, pumps, conditioners, etc) for the separation of the circuit. The analysis was done considering the production of 10 million tons per year of pellet feed.

\section{References}

ANFRUNS, J.J., KITCHENER, J.A. The rate of capture of small particles in flotation. Trans. Inst. Min. Metal., v.86, p. C9-c15, 1977.

BRANDÃO, P.R.G. Selectivity in the reverse flotation of iron ore: reagents adsorption. ENCONTRO NACIONAL DE TRATAMENTO DE MINÉRIOS, 21. Natal, RN, p.22-33, November de 2005. (In Portuguese).

COLLINS, G. L., JAMESON, G.L. Experiments on the flotation of fine particles. The influence of particles size and charge. Chem. Eng. Sci., v.31, p. 985-991, 1976.

DAI, Z., FORNASIERO, D., RALSTON, J. Particle-Buble Attachment in Mineral Flotation. Journal of Colloid and Intarface Science 217, p. 70-76, 1999.

FLINT, L.R., HOWARTH, W.J. The collision efficiency of small particles with spherical air bublues. Chem. Eng. Sci., v.26, p. 1155-1168, 1971.

GLEMBOTSKY, V.A. Investigation of separate conditioning of sands and slimes with reagents prior to joint flotation. INTERNATIONAL MINERAL PROCESSING CONGRESS, 8. Leningrado, 1968. Paper S-16.

GONZALES, G. Discussions and contributions. Trans. Int. Min. Metal., v. 87, p.C82-c83, 1978.

LIMA, N.P. Behavior of itabirite ores from Alegria and Fábrica Nova deposits in the desliming and flotation processes. Curso de Pós Graduação em Engenharia Metalúrgica e de Minas, Universidade Federal de Minas Gerais. March de 2001. (M.Sc thesis - In Portuguese).

OLIVEIRA, J.F. Mineral sector: technological trends. Centro de Tecnologia Mineral - CETEM. 2006. (In Portuguese).

REAY, D., RATCLIFF, G.A. Removal of fine from water by dispersed air flotation: effects of bubble size and particle on collection efficiency. Can. J. of Chem. Eng., v.51, p.178-185, 1975.

SUTHERLAND, K.L. Kinetics of the flotation process. J. Phys. Chem., v. 52, p. 394425, 1948.

TOMLINSON, H.S., Fleming, M.G. Flotation rate studies. In: INTERNATIONAL MINERAL PROCESSING CONGRESS, 6. Proceedings... Cannes, 1963. p. 563579.

ROBINSON, A. J. Relationship between particle size and collector concentration. Trans. Inst. Min. Metal., v.69, p. 45-62, 1975.

Artigo recebido em 03 de outubro de 2012. Aprovado em 13 de março de 2013. 